\title{
Alloplastic parieto-synthesis complications in abdominal wall reconstructive surgery - our clinical experience
}

DOI: 10.35530/IT.069.02.1451

DANA VASILESCU

ADRIAN PELINARU

SABINA IONITA

VICTOR GRAMA

ALEXANDRU CHIOTOROIU

\section{REZUMAT - ABSTRACT}

Complicații ale chirurgiei parietale aloplastice în reconstrucția peretelui abdominal - experiență clinică

În prezent, se consideră că tratamentul eventrațiilor nu este posibil fără utilizarea biomaterialelor. Deși sunt utilizate de mai multe decenii, fiind studiate și îmbunătățite continuu, în prezent trecem printr-o perioadă de stagnare. Din punct de vedere chimic, unele materiale sunt perfect biocompatibile, dar caracteristicile fizice și structurale ale diferitelor tipuri de proteze sunt asociate cu diverse complicații, inclusiv riscul de reacții ale corpului străin, infecție, formarea seromului, obstrucția intestinală, extrudarea implanturilor, malpoziție, malrotație, eroziunea viscerelor cavitare, apariția fistulelor digestive, eșecul reconstrucției.

În încercarea de a minimiza aceste riscuri cât mai mult posibil, este necesar să se cunoască mecanismele de apariție a unor eventuale complicații.

Cuvinte-cheie: eventratie, biomateriale, biocompatibilitate, proteze

\begin{abstract}
Alloplastic parieto-synthesis complications in abdominal wall reconstructive surgery - our clinical experience
Currently, it is believed that the treatment of eventrations is not possible without the use of biomaterials. Although they are used for several decades, being continuously studied and improved, now we are in a stalemate. Chemically, some materials appear to be perfectly biocompatible but the physical and structural characteristics of different types of prostheses are associated with various complications, including the risk of foreign body reactions, infection, seroma formation, intestinal obstruction, extrusion of the implants, malposition, malrotation, erosion of cavitary viscera, appearance of digestive fistulas, failure of reconstruction.

In an attempt to minimize these risks as much as possible, it is necessary to know the mechanisms of occurrence of potential complications.
\end{abstract}

Key-words: eventrations, biomaterials, biocompatibility, prostheses

\section{MATERIALS AND METHODS}

In order to objectify the complications of cure intervention of abdominal wall defects with alloplastic materials, we studied a total of 461 patients admitted and treated in Emergency Clinic Hospital, General Surgery Clinic II and Clinic of Plastic Surgery Reconstructive Microsurgery, between January 2005 and January 2010.

\section{DISCUSSION}

It is noted that an important etiopatogenic factor in the development of eventration was represented by obesity, which was present in $27 \%$ of cases.

The chronic respiratory diseases were often a reason for wound dehiscence, due to the effort of coughing. The impaired wound healing has been often caused by diabetes and hepatic cirrhosis.

In most cases (85\%) the eventrations were symptomatic and manifested by persistent abdominal pain, abnormal bowel movements, lingering parietal suppurations, digestive fistula after alloplasty. 228 patients $(49,45 \%)$ came with primary eventrations and $233(50,54 \%)$ with recurrent eventrations (figure 1).

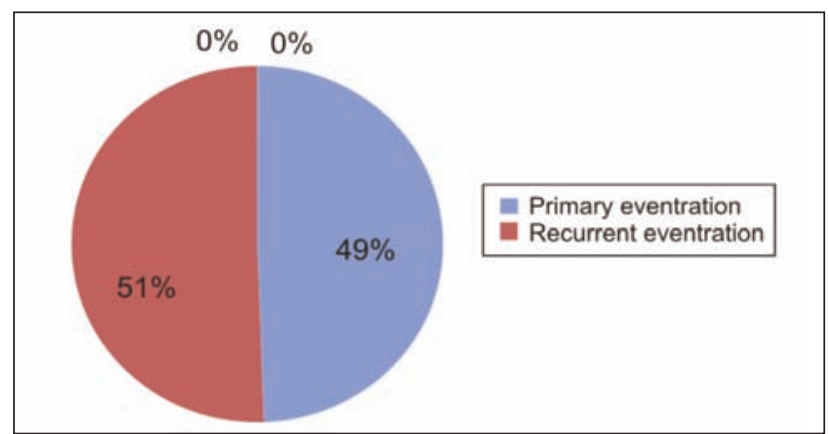

Fig. 1. Evantration cases

It should be noted that the patients with recurrent eventrations $-62 \%$ were in their first relapse, the rest having two or more relapses, with a maximum of 6 relapses.

As well, from the total recurrent cases, $58 \%$ had in their history a tissue parietal reconstruction and $42 \%$ an alloplastic reconstruction with polyesther prosthesis of autochthonous fabrication (PLASTEX).

Sixty-five patients with alloplastic parieto-synthesis in their history were admitted with a relapse of the parietal defect. Of these, 24 patients had also other late 
postoperative complications associated to the relapse: 13 patients - chronical parietal suppuration, 3 patients - digestive fistula, 6 patients - intestinal obstruction, 2 patients - parietal necrosis of the abdominoplasty flap (figure 2).

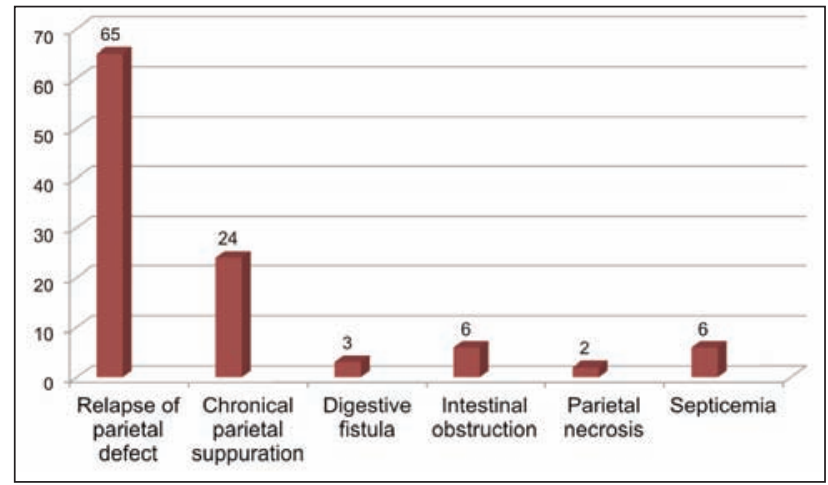

Fig. 2. Patients with recurrent eventrations

As concerns the localization of the eventration, most patients had vertical medial parietal defects and a small number of patients had other type eventrations (vertical paramedial, oblique and combined eventrations).

The vertical eventrations were of three types: medial, supra and subumbilicaleventrations in 240 patients; medial eventrations including the umbilicus - in 148 patients; paramedialventro-lateral eventrations, subcostal and iliac fossa - in 47 patients and dorso-lateral, diaphragmatic, perineal and parastomal - in 26 patients (figure 3 ).

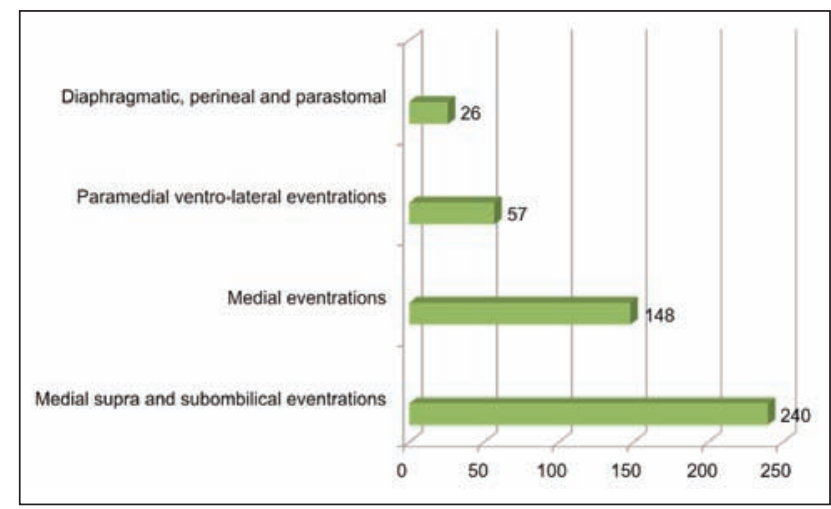

Fig. 3. Vertical eventrations

With regard to the intraoperative attitude, we found that in most cases it was possible an alloplastic parietal reconstruction in 254 patients; in the other cases -207 , the alloplasty was not possible at the first intervention because of the delayed post-operative complications, after a previous prosthetic reconstruction (chronical parietal suppuration - 13 patients, intestinal obstruction -6 patients, digestive fistula -3 patients), (figure 4).

The operative attitude ranged from primary prosthetic reconstruction to the draining of infections in lingering suppurations, removal of the previously implanted

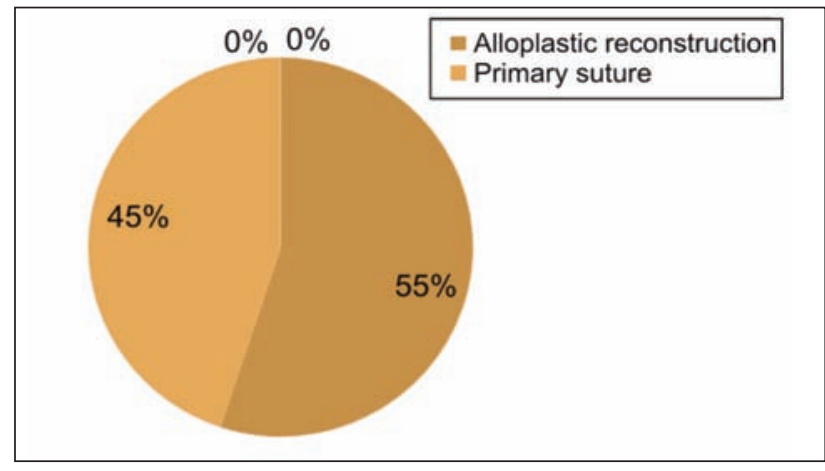

Fig. 4. Intraoperative attitude

mesh, segmented enterectomy in the digestive fistulas after alloplasty and occlusions.

Other interventions associated to alloplasty were cholecystectomy for simultaneous vesicular lithiasis in 6 cases and segmented enterectomy in 4 cases. Implantation (positioning) of the prosthesis was performed as follows: supra-aponeurotic of consolidation - 127 cases; pro-peritoneal of substitution - 103 cases; intraperitoneal of substitution - 24 cases (figure 5).

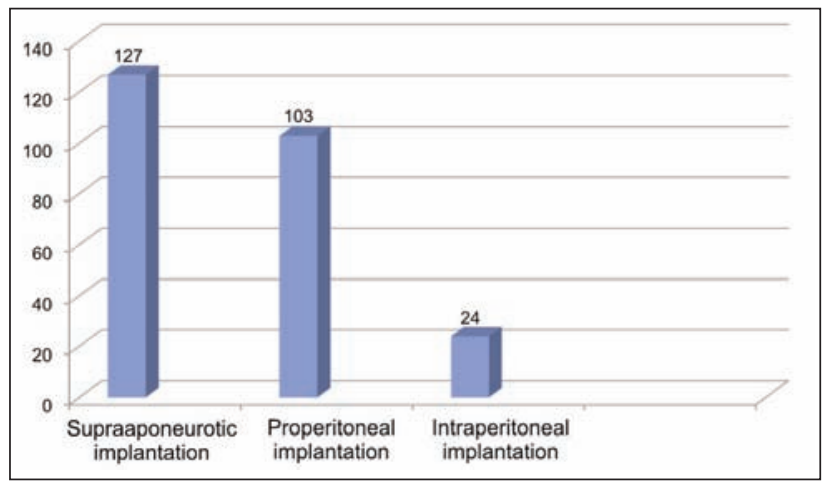

Fig. 5. Implantation pozition

With regard to the severe postoperative complications after alloplasty we found the following:

The parietal suppurations were in all cases lingering, with durations ranging from 1 month to 2 years. In all cases suppuration occurred after the use of autochthonous mesh (Plastex), generally in tarred patients with significant comorbidities.

In all cases it was required the drainage of the infectious process after the complete removal of the previously implanted prosthesis, the excision of compromised tissues.

It should be noted that in all cases the prosthesis was largely or wholly unincorporated and the pus cultures were sterile.

In most cases at the same time was performed the alloplastic parieto-synthesis under intensive antibiotic therapy and drainage.

The postoperative morbidity and mortality was $0.4 \%$, a patient dying in the hospital through portal hypotension on decompensated cirrhosis. The postoperative complications were divided into early and late 


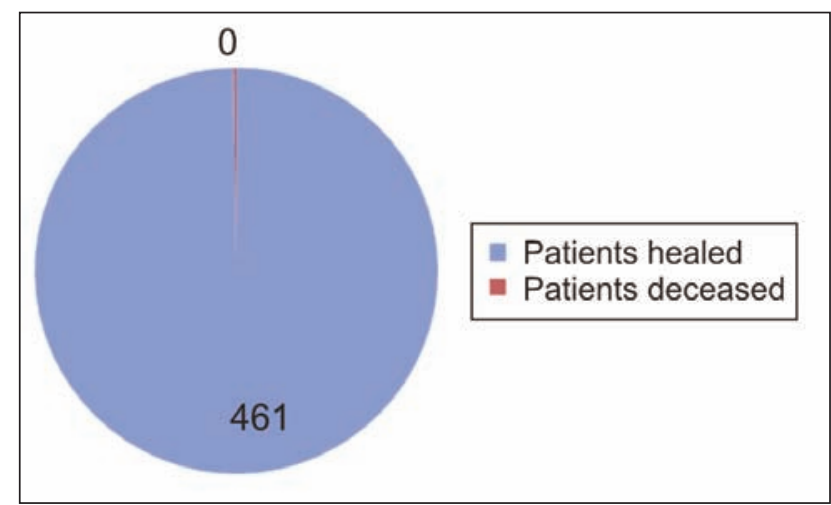

Fig. 6. The postoperative morbidity and mortality

complications, respectively in local and general complications (figure 6).

The recorded local early complications were in order of their frequency: wound infections, hematoma, seroma, dehiscence of the surgical wound.

The general early complications had an incidence of $2-4 \%$, consisting of respiratory disorders, heart rhythm disorders particularly in obese patients with chronic respiratory disease, ischemic heart disease or hypertension.

The late complications have been linked to the presence of the prosthetic material and consisted of chronic parietal suppuration with rejection of prosthetic material, relapses of eventrations, intestinal occlusions.

The intestinal obstructions (through intestinal adhesions on the surface of the prosthesis) and the digestive fistula (through erosions induced by the prosthesis) were recorded after intraperitoneal placements of some polyester prostheses after 1-6 years interval.

It should be noted that in parietal suppurations, the removal of the old prosthesis was required only for polyester prosthesis. Polypropylene not only did not require this, but was incorporated, even in the presence of an infection.

In patients operated for giant postoperative eventrations, including also a septic time (segmental colectomies, enterotomies) to whom was used a polypropylene prosthesis, the evolution has been favorable.

Seroma recorded in this study occurred after supraaponeurotic and pro-peritoneal alloplasty. Factors that cause them are the "dead space" which is inevitable in giant defects and the type of prosthesis. The solution is the use of macroporous mesh (polypropylene) and/or drainage suction [1-2].

The parietal infections were recorded after intraperitoneal and supra-aponeurotic alloplasty, especially after the use of "Plastex" mesh. Most often, the parietal suppuration was lingering, the patients being operated repeatedly. We have found that the excision of the fistulous tracts, of stitch granuloma and the partial removal of the polyester prosthesis were not sufficient; only the complete removal of the mesh solved the problem definitively.

The failure of reconstruction is the rule in cases where we are dealing with chronic parietal suppurations, if it was used a prosthesis made of polyester. In such cases, suppuration is a warning to the surgeon who must realize that under these conditions, the incorporation of the prosthesis is compromised.

Unlike polyester, polypropylene is inert in the presence of infection and the local toilet is sufficient. However, if the prosthesis was fixed with nylon stitches, it is necessary their removal as they maintain the parietal suppuration [4].

The risk of infection during a prosthetic implant is always possible, even if it is not completely clear in terms of incidence, severity and consequences.

In this case it is recommended the use of "clean" surgical techniques, which means the careful handling of the tissues, surgical field and prosthesis [5].

As seen, some authors recommend even the abstention from alloplasty when the surgical field is contaminated [6].

Prosthetic rejection can occur even in the absence of suppuration. Of the several types of used prostheses, we found that only for the polyester prosthesis (Plastex), which shows that this one has problems of "biocompatibility" [7].

Another cause of relapse that we have recorded in our study is the technical defect concerning the way of prosthesis fastening. In this respect, in all cases where the overlapping of prosthesis - musculoaponeurotic edges was less than $5 \mathrm{~cm}$, the patients returned for early relapse after a short period $-1-3$ months.

In the prophylaxis of mesh disinsertion and relapse, the experts of parietal surgery recommend to keep a safety margin of at least $5 \mathrm{~cm}$, especially at the upper and lower pole [8]. We should not forget that parietosynthesis should be performed without tension ("tension-free") or with a lesser tension at the suture line. Neglecting of this fact is equivalent to the occurrence of relapse [9].

It should also be noted that under anesthesia the parietal tension is always lower than in the post-anesthetic period. In this regard, the consolidation alloplasty can be risky in giant eventrations, even if relaxation incisions are used [10].

In the absence of intraoperative tensiometry, the choice of the surgical technique was based on subjective criteria, in terms of personal experience. On the other hand, the prosthesis should not be set under tension because it changes its size in time, usually in the sense of contraction [11]. Of the types of used prostheses, the best results were obtained with MARLEX prosthesis. This coincides with data from international literature, where it is considered that polypropylene prosthesis is closest to the qualities of the "ideal" biomaterial.

The intestinal adhesions to the prosthesis, usually occur when the mesh is placed intraperitoneally, in contact with the viscera. Their erosion may result in the appearance of digestive fistulas, up to the migration of the prosthetic material into the lumen [12].

As we have noted in the clinical study, the prosthesis may erode both in the small bowel and colon, stomach 
or duodenum. In these cases the evolution is often difficult, with the possibility of occurrence of other postoperative complications, with major vital risk.

In fact, the most difficult situation occurs when the peritoneum cannot be reconstituted and we have to position the prosthesis intraperitoneally. In this case, the best solution is the use of COMPOSIX prosthesis, considered to be best to ensure an appropriate tissue penetration and on the other side (the intestine side) a resorbable and tissue impenetrable membrane, in order to prevent the formation of adhesions and bowel fistula.

The excessive parietal tension can also cause severe respiratory and cardiovascular disorders due to the significant increase of the intra-abdominal pressure. This results in the decrease of the compliance of the chest wall with the increase of the mechanical respiratory effort [13].

Without the use of computerized systems for intraoperative measurement and correlation of the respiratory parameters, the assessment is difficult and subjective.

In addition, the deep muscle relaxation during anesthesia causes the parietal tension to be lower than in reality. We can say that giant postoperative eventration represents a true challenge both for the surgeon and the anesthesiologist.

In terms of the surgical technique, from the clinical trial results that the pro-peritoneal parieto-synthesis of substitution had the best results, provided the use of a quality prosthesis.

\section{CONCLUSIONS}

Finally, following an alloplastic parieto-synthesis all the surgeons want to preserve the physiological elasticity of the abdominal wall and the prosthesis be adjusted to the required resistance and allow an adequate tissue integration. The polypropylene prostheses show a good mechanical stability and a reasonable elasticity. The common materials with small pore size result in a foreign body reaction of relatively long duration and a strong active inflammation.

On the other hand, the conventional prostheses seem to be considerably oversized. The use of an unnecessary excess of material may lead to an excess of foreign body reaction and of an inflexible cicatricial "breastplate", perceived by patients as a "stiff abdomen".

It remains open the subject of foreign body reactions, which is a specific problem of alloplastic reconstructions, although sometimes underestimated.

As it was shown, the intensity of these reactions depends on the host tissue reaction, the amount of material and the structure of the prosthesis. The late parietal suppuration, the formation of adhesions or the migration/rejection of the prosthesis are the result of an inflammatory response, which is a major problem for some patients.

The long-term postoperative follow-up of the patients is essential to assess the real result of the intervention. The patient should be instructed to come regularly to control because he /she can overlook the signs of severe late complications.

The experts in parietal surgery recommend a followup period of 5 years.

\section{CLINICAL CASES}

\section{Subumbilical medial eventration repaired with da Vinci robot}

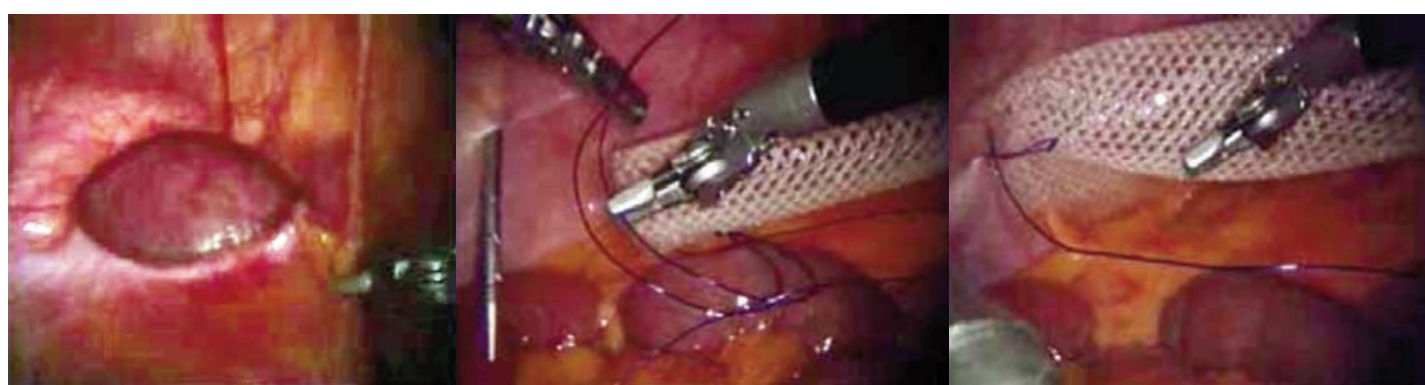

Post Burcheventration Fastening of the first mesh stitch First mesh stitch knotted

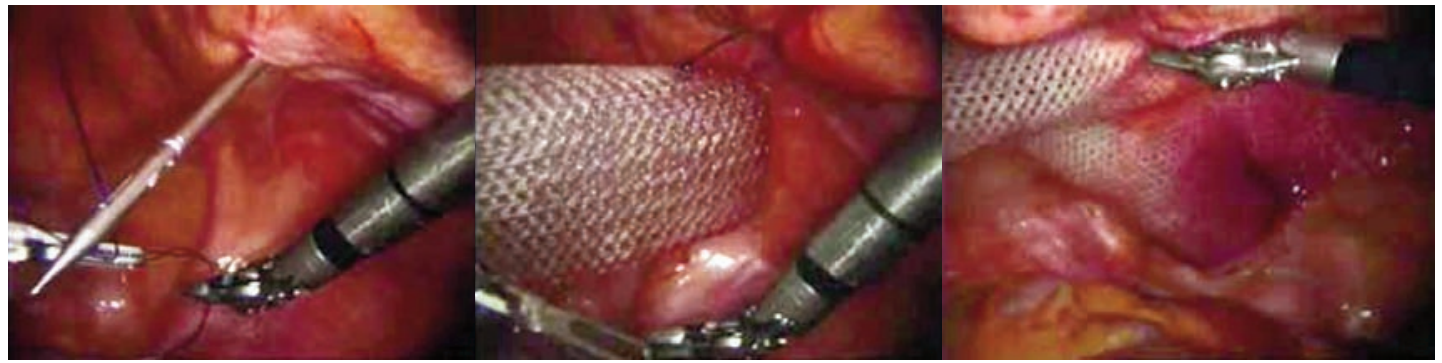

Fastening of the second Second mesh stitch knotted Mesh layout mesh stitch 


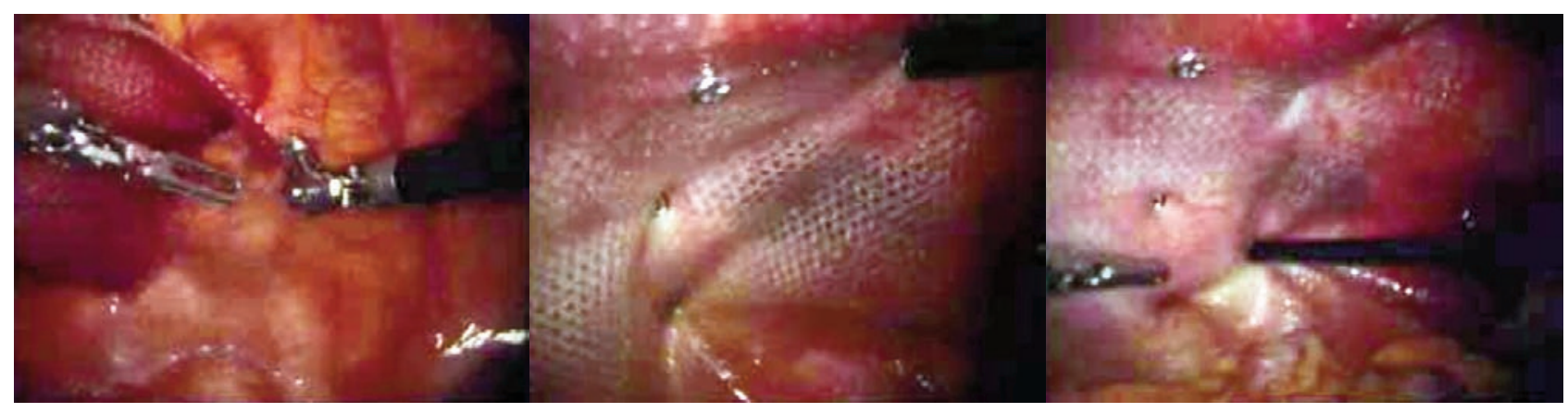

Suture of mesh margin Tackers

Mesh fastened with Tackers

Mesh fastened witharound the defect

Laparoscopic hernia repair

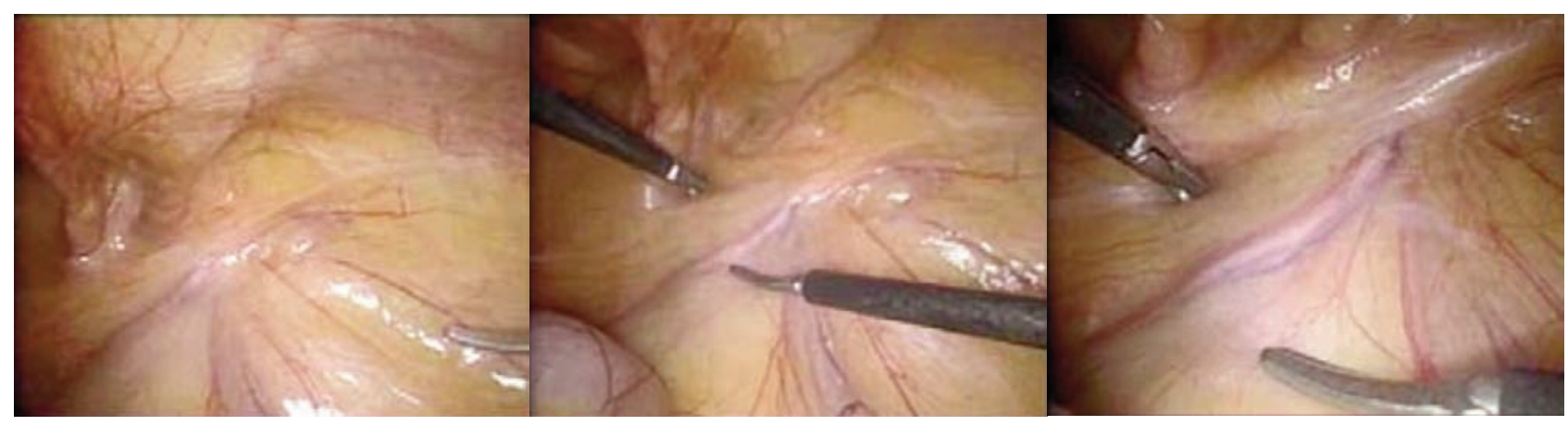

External oblique inguinal hernia (right side)

Right deferent duct

Right deferent duct-2

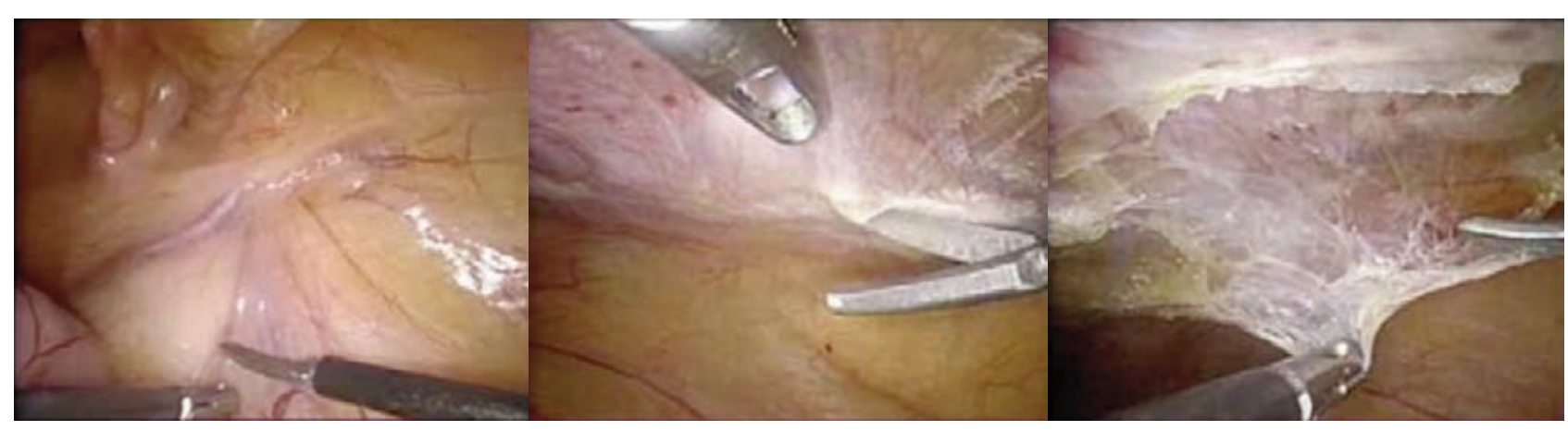

Spermatic vessels

Incision of parietal peritoneum

Dissection of parietal peritoneum, lower margin

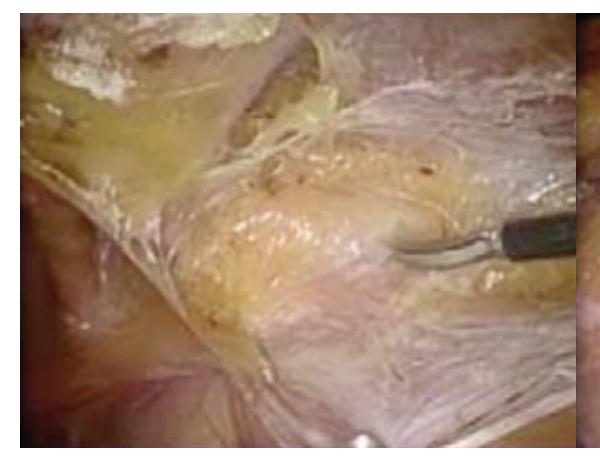

Dissection of the properitoneal space at the internal inguinal opening

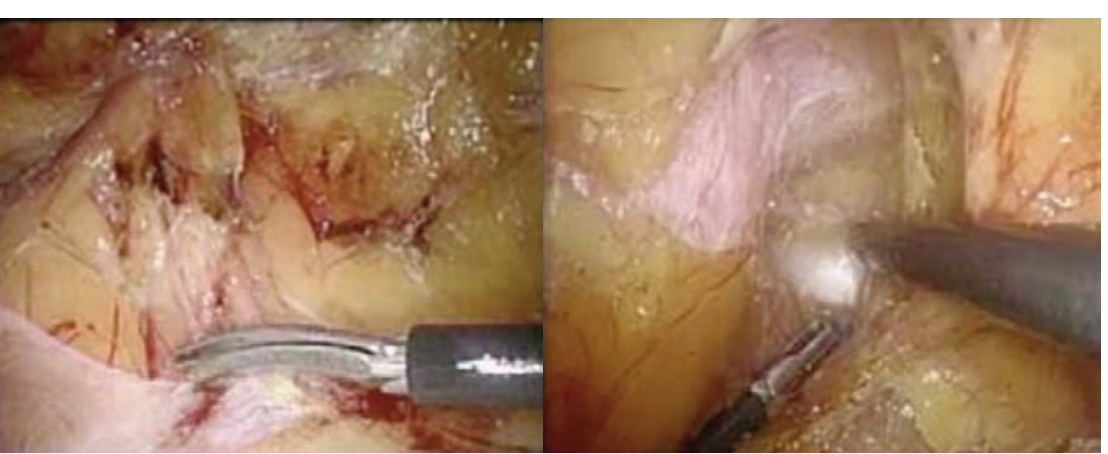

Release of spermatic funicle with fat from the marginal parietal peritoneum 


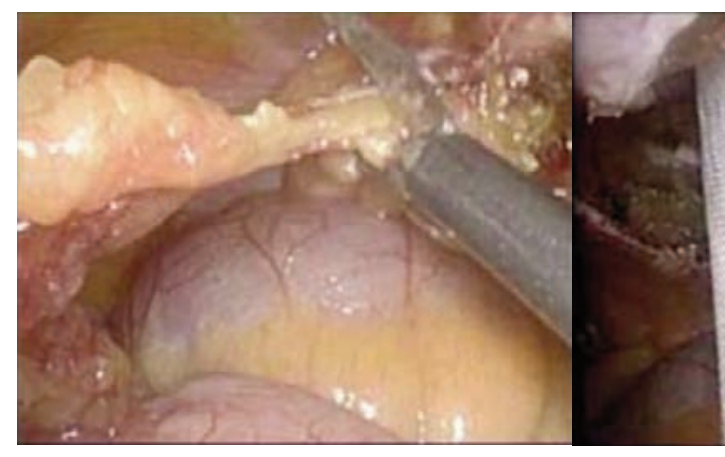

Excision of the

lipomathepolypropylene mesh

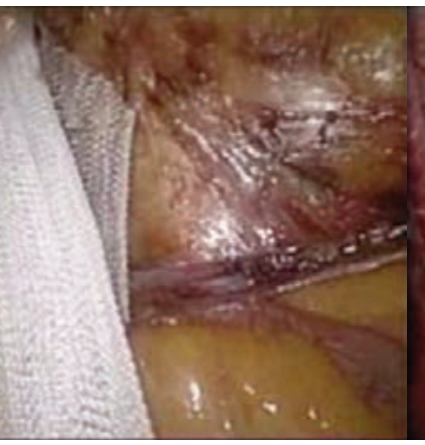

Introduction of the right inguinal region

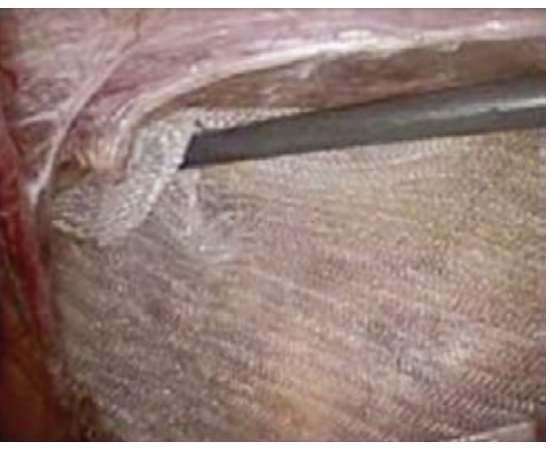

Layout of mesh ovepre-hernia

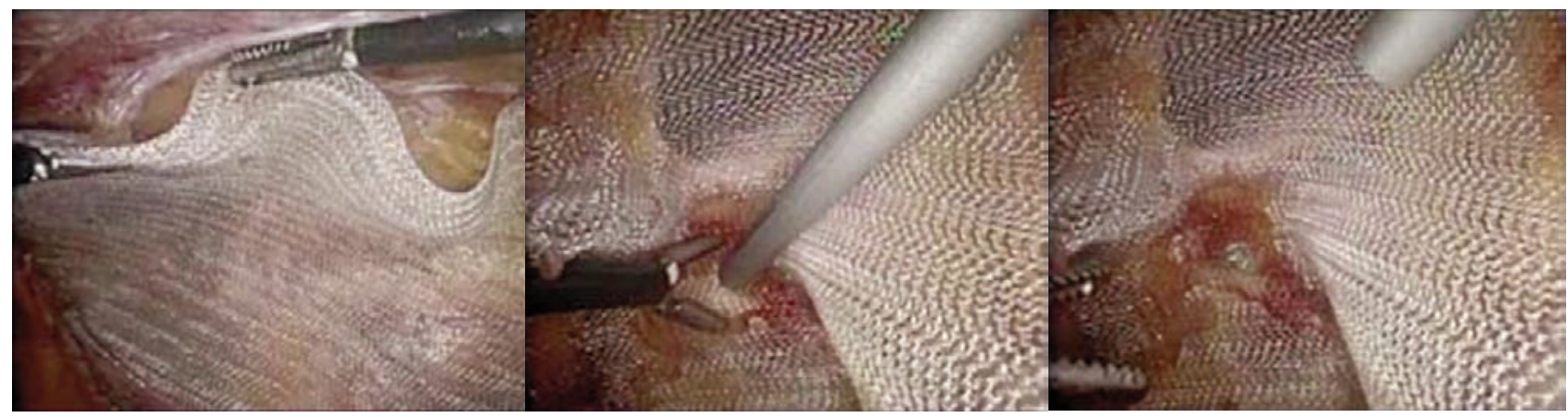

End of mesh layout

Mesh fastened with Tacker

Cooper ligament with Tacker

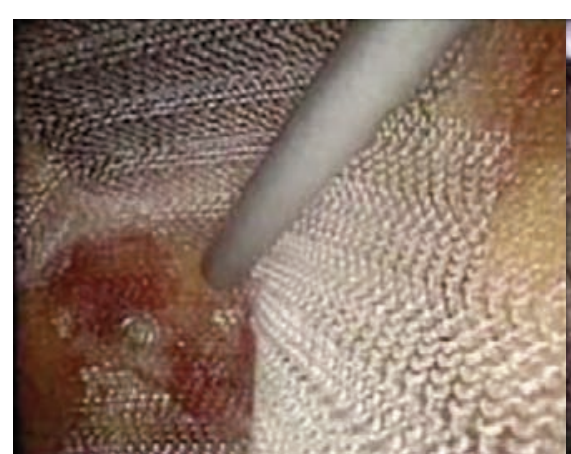

Mesh fastened with Tacker-2

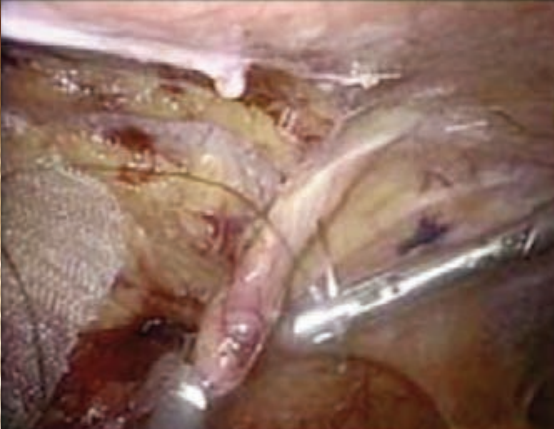

Beginning of parietal peritoneum suture

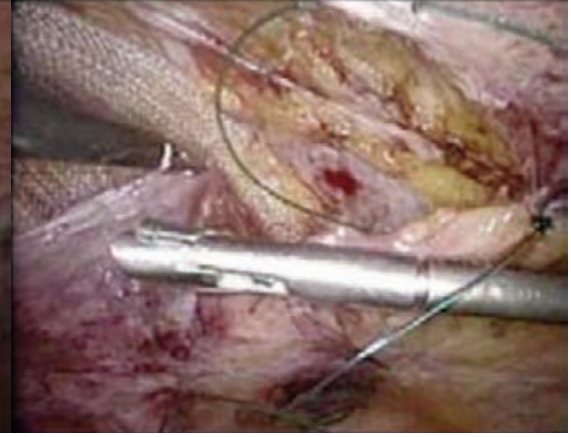

Continuation of peritonization

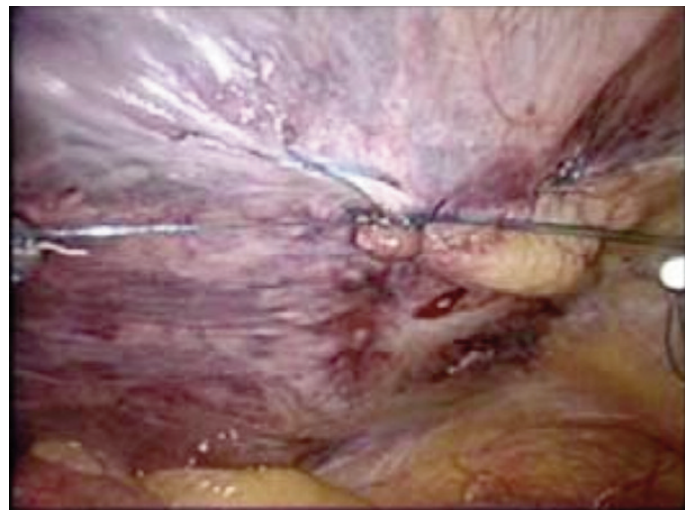

End of peritonization 


\section{BIBLIOGRAPHY}

[1] Feliciano, A., Bartonem G., Fei, L. Incisional hernia, Springer Verlag, 2008.

[2] Boissel, P., Proye, C. Patologie chirurgicale, Ed. Masson, 1991.

[3] Burgard, G., Marmorale, A., Cuilleret, J. Traitement des grandes éventrations abdominales par plaque intrapéritonéale agrafée, In: J. Chir. (Paris), 1994.

[4] Ciurea, M. Texturi sintetice în chirurgia reparatorie a peretelui abdominal, In: Chirurgia, 1998.

[5] Deac, D. Utilizarea protezelor sintetice în chirurgia defectelor peretelui antero-lateral. Ed. Clusium, 1999.

[6] Delay, E., Rivoire, M., Bobin, J.Y., Frane, C. Réconstruction des vastes pertes de substance de la paroi abdominale inférieure, In: Lyon Chir., 1993.

[7] Gould, B. Collagen biosynthesis in wound healing, USA National Research Council 1996.

[8] Slim, K., Pezet, D., Chipponi, J. Les grandes éventrations de la paroi abdominale: un technique de plastie aponevrotique associée à une prothèse. In: Presse Med., 1994.

[9] Soler, M., Verhaeghe, P., Essomba, A., Sevestre, N., Stoppa, R. Treatment of postoperative incisional hernias by a composite prosthesis (polyester - polygalactin 910). Clinical and experimental study. In: Ann. Chir., 1993.

[10] Stoppa, R., Henry, X., Abet, D., Verhaeghe, P., Largueche, S. Que faire devant une éventration post-opératoire. In: Cah. Med., 1979.

[11] Stoppa, R., Moungar, F., Verhaeghe, P. Traitement chirurgical des éventrations medianes sus-ombilicales. In: J.Chir., 1992.

[12] Schwartz, G., Brunicardi, F., Andersen, D., Billiar, T., Dunn, D., Hunter, J., Matthews, J., Pollok, R. Principles of Surgery, 9th Edition 2009.

[13] Voinchet, V., Aubert, J.P., Berthet, B., Mulfinger-Audiffret, C. Apport de la plastie abdominale dans le traitement des éventrations non-compliquées de la paroi abdominale. In: J.Chir. (Paris), 1994.

Authors:

\section{Dr. DANA VASILESCU ${ }^{1}$, \\ Dr. SABINA IONITA ${ }^{1}$, \\ Dr. VICTOR GRAMA ${ }^{2}$, \\ Dr. ADRIAN PELINARU ${ }^{1}$ Dr. ALEXANDRU LAURENTIU CHIOTOROIU ${ }^{2}$}

${ }^{1}$ Plastic and Reconstructive Surgery - Floreasca Hospital Emergency Bucharest Romania

${ }^{2}$ General Surgery - Floreasca Hospital Emergency Bucharest Romania

All authors had equal contribution to this article

Corresponding author:

Dr. DANA VASILESCU

e-mail: dr.danavasilescu@hotmail.com 